\title{
Corporate Disclosure and the Deregulation of
}

\section{international investment}

\author{
David Bailey Research Centre for Industrial Strategy, University of \\ Birmingham and Institute for Industrial Development Policy \\ George Harte \\ Department of Accounting and Finance, University of Glasgow \\ Roger Sugden \\ Institute for Industrial Development Policy and University of \\ Birmingham
}

We would like to acknowledge the helpful comments of a number of colleagues, including participants at seminars at the University of Birmingham and Glasgow Caledonian University, Carol Adams, David Cooper, Andrew Hawker, Ken McPhail, Martin O'Donnell, the late Tony Puxty, Colin Rickwood, Fenton Robb and two anonymous referees. We would also like to thank Kirsty MacCallum, Wards Librarian, for her research assistance.

Correspondence; please contact David Bailey, Research Centre for Industrial Strategy, Department of Commerce, The Birmingham Business School, University of Birmingham, Edgbaston, Birmingham B15 2TT, England. email D.Bailey@bham.ac.uk

Keywords; accountability, deregulation, Multilateral Agreement on Investment, monitoring, social reporting, transnationals.

Please do not quote from this paper without the permission of the authors. 


\title{
Corporate Disclosure and the Deregulation of
}

\section{international investment}

\begin{abstract}
$\underline{\text { ABSTRACT }}$
Drawing on evidence of major Western governments' concerns with the wider economic, social and environmental impact and performance of transnational firms, we argue that recent emphasis on deregulating industrial development, such as in the proposed Multilateral Agreement on Investment and ongoing discussions over a multilateral framework on investment, necessitates a fuller and regulated, rather than voluntaristic, corporate accountability, covering further details of the impact and performance of transnationals.
\end{abstract}

\section{$\underline{\text { INTRODUCTION }}$}

This paper examines the accountability of transnational corporations in light of recent 'deregulation' of international investment and trade flows. Drawing on evidence of major Western governments' interest in transnationals ${ }^{1}$, which revealed a concern with the wider economic, social and environmental impact and performance of such firms, we consider recent proposals which threaten national and local government sovereignty in industrial development. Ironically, the emphasis on markets, in contrast to the regulation of industrial development, is argued to necessitate a fuller and regulated corporate accountability, with further details of the impact and performance of transnationals. The preference for market 
based solutions to the problems of industrial development is seen to necessitate the regulation of corporate reporting so as to facilitate the monitoring of transnational corporations. In the following section we consider the nature of transnational corporations, before outlining proposals for the monitoring of such firms.

\section{TRANSNATIONAL CORPORATIONS}

The key characteristic of transnational corporations (transnationals) is their international production. Such firms are involved in capital accumulation on a global scale, operating global strategies to produce continued growth (Sklair, 1991). Various theories of the transnational have been put forward, including the monopolistic advantage approach of Hymer (1960) and Kindleberger (1969), and the eclectic analysis of Dunning (1977, 1979, 1980 and 1981) (see the surveys by Cantwell (1991), Dunning (1993) and Dicken (1998)). Particularly influential has been transaction cost analysis (see for instance Buckley and Casson (1976) and Hennart (1991)), with its roots in Coasian theory of the firm (Coase, 1937). The basic premise of this analysis is that a transnational firm involves co-ordination of production across national boundaries, in order to save transaction costs. This is achieved by using non-market transactions to bypass imperfect markets.

However an alternative view can be taken. This is rooted in the analysis of monopoly capitalism (Baran and Sweezy, 1966; Cowling, 1982), which disputes the Coasian assumption of an even distribution of power, going beyond the Coasian superficial obsession with markets and focuses on distributional issues rather than Pareto efficiency (Cowling and 
Sugden, 1987 and 1998a). A transnational is seen as "the means of co-ordinating production from one centre of strategic decision making when this co-ordination takes a firm across national boundaries" (Cowling and Sugden, 1987). This definition emphasises the importance of control, and in particular strategic decision making, rather than market exchange, and sees firms becoming transnationals in order to defend themselves against or attack oligopolistic rivals, in order to maximise returns to owners of capital (Cowling and Sugden, 1987). Moreover transnationals are argued to behave in a manner of divide and rule (Sugden, 1992 drawing on Marglin's analysis (Marglin, 1974) and Peoples and Sugden (1998)). They encourage nations and communities to compete, being in a powerful position since neither can be mobile, unlike the transnational which is free to 'roam the world' (Barnet and Cavanagh, 1994). Transnationalism, particularly for the giant firms, gives additional leverage (with this greater potential to shift operations) and leads to such problems as monopolisation, deindustrialisation and the undermining of democracy (Cowling and Sugden, 1987 and 1993). Although states can have considerable regulatory powers, transnationals possess real economic power with the threat of withdrawal, redundancy or the promise of investment as a counter to government desires to impose some control (Murray, 1981) ${ }^{2}$.

Similar concerns have been expressed about transnationals' activities, including their homogenising effects, their insensitivity to local needs, stifling of local initiatives, sovereignty and autonomy (Hood and Young, 1979), as well as their power to erode the state's capacity to control its economic future (Held, 1988, Wilms Wright, 1977). This is of particular importance since transnationals are fundamentally undemocratic organisations, with management being accountable primarily to capital markets. In contrast there is little or 
no opportunity for stakeholders or those affected by transnationals' activity (e.g. the community) to influence corporate policy other than in the fragmented market for consumer goods or in the electoral ballot (though not the corporate ballot).

The rise of transnationals has also meant that many aspects of economic decision making have been taken out of the hands of government (Labour Party, 1977). This process has accelerated in recent years, following the General Agreement on Tariffs and Trades (GATT), the North American Free Trade Agreement (NAFTA), as well as the recently proposed Multilateral Agreement on Investment (MAI) and on-going discussions over a multilateral framework on investment. Yet, despite this increasing loss of sovereignty, states appear to have little information on the operations and impact of transnationals. In contrast a transnational will monitor the performance of its divisions and subsidiaries (Labour Party, 1977) not to mention its employees and rivals and collect information on those countries in which it is located, relies on for supplies and in which it sells.

In the following section we consider the main arguments for regulating transnationals, in particular the case for the setting up of state monitoring units. In doing so our focus is with the essence of the characteristics and activities of transnationals, regardless of their so-called nationality. In doing so we will draw on research which indicates the interests of western industrialised countries in transnationals over time (for an argument that the essence of their characteristics is not nation specific see Cowling and Sugden (1998a)). 


\section{TRANSNATIONALS MONITORING UNIT}

Clearly transnationals are already regulated to some extent. Like other firms they will be governed by national legislation and local regulation, as well as by other formal and informal contracts with stakeholders. However the view of transnationals presented here suggests that largely as a result of their pursuit of private profit, their size and their potential for geographical mobility, they pose particular problems for nation states and communities. The asymmetry of power between transnationals and national communities suggests that nations should adopt a coherent economic strategy to counter such power (Cowling, 1990), rather than simply competing to attract investment. This is not to suggest that transnationals do not bring benefits. All forms of economic activity will bring benefits, since consumption inevitably creates employment. In the case of transnationals these may be well paid jobs, with good working conditions, the development of local supplier linkages, contributions to the local exchequer, and exports and reduced imports, which will benefit the balance of payments and local currency. However, although such benefits may exist, they may not represent the best that can be obtained in the circumstances. There might also be the chance to reduce costs imposed on the community by transnationals.

The case for regulating transnationals as part of a coherent economic strategy rests largely on their material impact, their manipulation of imperfect markets and the conflict of interests with the community ${ }^{3}$. Otherwise unregulated transnationals are able to impose their strategies on more or less 'enslaved' communities (Cowling and Sugden, 1993), where "concentrated decision making power in a free market economy results in an elite planning for its benefit 
and without regard to the costs imposed on others" (Cowling and Sugden, 1993). As control over such strategic decisions as investment, output, employment and other issues becomes more firmly enshrined in the hands of a few elite decision makers, the risks of 'strategic' failure become more significant, where the objectives of elites conflict with wider interests in society (Cowling and Sugden, 1994). The end result is social inefficiency, with the economic system yielding inappropriate outcomes for the society (or societies) served by that economy.

It is for these reasons that a transnationals monitoring unit has been advocated as a contribution to the development of strategy towards transnationals. A monitoring unit would collect information and inform government policy making, enabling the development of a more active economic strategy in the interests of the community. This policy is advocated not because of some belief that transnationals act in a harmful manner necessarily intentionally, but that consequences harmful to the community arise from their participation in a market system, and the way that system combined with its participants is developing. This is not to deny the possibility of transnationals developing benevolent economic, social and environmental policies which appear to reduce profitability ${ }^{4}$. However in general we would expect managers to put the welfare of owners of capital before the interests of the community and the workforce, never mind the environment, particularly in the context of recent deregulatory policies. Later, in our discussion of the need for a better developed accounting for transnationals, we draw on this recognition of underlying and irresolvable conflict of interest between labour and capital, in our use of a political economy perspective (Cooper and Sherer, 1984; Ogden and Bougen, 1985). 
While transnationals would not willingly accept our advocated regime, and whilst we have argued that transnationals typically posses considerable power, they are not all-powerful. As in any social relationship there would appear to be room for at least some manoeuvre, although presumably transnationals would prefer to have everything their own way. For example, while valuing the freedom given to them by the state, transnationals may be willing to accept greater regulation of accountability (e.g. in disclosure) in return for further deregulation of economic activity, such as proposed in the Multilateral Agreement on Investment and current discussions over a multilateral framework on investment. There is evidence that even those policy makers very resistant to the idea of controlling transnationals, for fear of their reaction, have been willing to contemplate monitoring (for example the Labour Party leadership in Britain in the late 1980s (The Guardian, 2 June, 1987).

In fact holding the view that transnationals are too powerful to resist, paradoxically strengthens the case for a monitoring unit (see Harte and Sugden (1990) footnote 7, p 148). This suggests the need to consider policies which will allow the community to become a more equal partner in industrial development. Clearly an important aspect of any monitoring should be the evaluation of the impact of the unit and its impact on transnationals' activities, in particular whether disclosure results in greater equality of knowledge. In a similar vein the recent history of utility regulation in Britain has revealed a struggle over information, yet the infrastructure of regulation remains in place.

The idea of a monitoring unit has been proposed at various times in the past (e.g. Wilms Wright, 1977; Labour Party, 1977; Hughes, 1986; Labour Party, 1987; Standing Commission 
on the Scottish Economy, 1990; European Parliament, 1999 $)$ generally to find out more about business plans and to allow better negotiation with (foreign) corporations (Labour Party, 1987). Wilms Wright's proposals follow from the identification of conflicts of interest (e.g. in regard to sovereignty, investment policy, pricing and trading policy, monopoly power, monetary policy, and labour relations). He argued that legislation is needed to develop a framework for the control of transnationals, suggesting that such was already in place in a number of countries, notably Canada, and referred to the development of codes of conduct by UN, ILO and OECD. However his proposals were substantially more radical and include the development of international trade union co-operation, the encouragement of government economic and industrial policies to benefit domestic firms and specific measures to deal with transnationals (planning agreements between firms and government, greater supervision of inward investment, greater scrutiny of outward investments where these exploit workers abroad, and legislation to deal with restrictive business practices, tax evasion and the impact of transnationals on monetary and trade policy). Greater disclosure of financial and other information was also advocated.

The proposals of the Labour Party (1977) are contained in a 135 page report which described the rise of the transnational and the problems caused for communities (particularly the loss of economic power, the effects of company pricing strategies, transfer pricing, impact on balance of payments and trade, technology, and the impact on trade unions). In particular the report emphasised the need to have a great deal more information on the activities and consequences of transnationals. Although it was recognised that there are occasions when government departments are entitled to information from transnationals (e.g. through the then 
Exchange Control Act, 1947, the Monopolies and Mergers Commission, etc.) it was suggested that governments did not know whether undertakings given by firms provided with financial and other assistance had been delivered. In addition it was suggested that a substantial number of foreign owned establishments in Britain (just over half) were branches, which did not need to supply information to Companies House ${ }^{6}$. The conclusion was that new government powers were needed, including greater rights to information and the introduction of planning agreements. A Foreign Investment Unit was proposed, which would examine all transactions with transnationals. The Unit was intended to gather information so as to facilitate policy making, to enable government to behave much more like a conglomerate. In this sense transnationals were being viewed as subsidiaries of the state, and so expected to disclose information to allow the state to manage the economy. Following a long list of information which it was felt needed to be disclosed the report recognised that the methods of accounting were a concern, suggesting that 'accountants wield so much power that they cannot be left as they are'.

However a unit's potential is much greater and, we would argue, of greater significance with the deregulation of industrial development. It could provide a pool of knowledge influencing government policy, provide a means for wider public accountability of the performance and impact of transnationals, challenging the language of traditional accounts of business performance, be an important institutional catalyst, and possibly affect the policies of transnationals directly. The role of a monitoring unit would therefore be to collect information, prepare accounts of the performance and impact of transnationals and use these to influence (government policy, community attitudes and even corporations themselves). In 
this a monitoring unit would be performing a task similar to equity analysts, who monitor the performance of actual and potential investments using a variety of sources including the corporate report, so as to construct their own understanding or account of the past and future performance of firms. The monitoring bodies we envisage might thus prepare "economic and social accounts" of transnational firms' activities, drawing on approaches in the social auditing literature to investigate their wider economic and social impact. The exact format of such accounts would be decided in conjunction with community players, but might cover issues such as: ownership and control, competition, research and development, employment and industrial relations, balance of payments impact - all matters of concern to some Western governments in recent years (see below).

We might also envisage a monitoring body catalysing wider community groups; consumers, workers, smaller firms and so on. Some action in monitoring transnationals has already begun in Europe by organisations such as the Centre for Research on Multinational Corporations (SOMO) based in the Netherlands, and in Britain with Ethical Consumer and New Consumer, as well as by ethical investment services such as EIRIS (Ethical Investment Research Services) and PIRC (Pensions Investment Resource Centre). Complementing this, there has also been a growth in interest in social auditing by organisations connected with the 'new economics' movement. This is seen both in publication of actual social audits, and in the recently developed SA 8000, a standard on social accountability (CEPAA, 1997), and the development of human rights principles for companies (Amnesty International, 1998). Such activity could be further encouraged through creating monitoring bodies across, say, Europe, which would network with such community groups. Finally this might also encourage new 
forms of internationalism, such as 'multinational webs', particular types of production networks, as a potential alternative to the internationalism of transnationals (Sugden, 1997) ${ }^{7}$.

We should, however, note that competition between nation states (as seen in respect of subsidies, taxes, wages, employment and legislation, etc.) is also possible in respect of the idea of a monitoring unit. It may well be that countries would compete to drive down the terms of any monitoring. Transnationals might decide not to invest where there is monitoring, so long as there is an alternative with less demanding or no monitoring. This suggests that monitoring is best conducted in a co-operative manner, across states (Harte and Sugden, 1992), although the idea of setting up some international monitoring body as a first step seems daunting in comparison to the formation of national bodes, with some agreement to share information ${ }^{8}$.

While the detailed workings of a monitoring unit are beyond the scope of this paper, a potential framework has been seen in attitudes to transnationals expressed by governments in Britain, France, Germany, Japan and the USA ${ }^{9}$. This has indicated a wide range of interests, with the following appearing to be most frequently identified; 
Table 1 Examples of Western Governments interest in Transnationals over the last 30 years

Ownership and control

Competitive implications
Concern regarding takeovers; changes in ownership; structure of the enterprise; local participation as shareholders; local management/directors; importing managerial techniques; concern to protect key sectors (not technological); loss of decision making power

Concentration/market share/industrial structure; marketing: pricing: marketing policies/strategies: distributional impact; 'pressure' on small and medium sized local businesses; concern over licensing/technical agreements e.g. restrictions on price; not access to most 'lucrative' (highly profitable) sectors; levels of concentration of foreign ownership in the industry; prevention of a competitive challenge in a particular sector.

Research and development Concern to protect key sectors; R\&D/technological processes /technology the firm can bring or take abroad ('technological impact'); ownership/transfer of technology and dependence; product innovation /variety /quality; training; whether encourages or discourages national research; 'accelerating modernisation'; concern that the most profitable or advanced production activity would be saved for the foreign parent.

Employment and industrial Rate of 'exploitation'; conditions of work and life; job quality; relations job security; employment; equality of opportunity and treatment; impact on industrial relations/trade unions; competition for scarce labour

Balance of payments Currency stability (including financing); currency /international trade convertibility; size of capital outflows/repatriation of profits; balance of payments.

Compliance/co-operation Whether 'indifferent to national interests'; impact on the 'smooth running' of the economy or its rehabilitation; maintenance of order in native firms/whether adversely affects domestic firms; whether supplements domestic investment activity; scale relative to national investment levels; compliance with monetary policy; impact on economic independence; contribute to 'self support and sound development of the economy'; inflationary impact; impact on national income/production. 
Political issues

Political involvement/donations; to/from which country (foreign policy issues); whether from a foreign government; whether has 'harmful' political consequences; impact of foreign legislation

Overall, British policy makers in particular appear to have shown a comparative lack of interest over the last 30 or so years, in contrast to the concerns of their counterparts in France, Germany, Japan and the USA. Although we will not address comparative responses in detail here, elsewhere we have documented the similarity in the interests of western industrialised countries over time (Bailey et al, 1994b). More recently, for example, the growing concern in Japan with the 'hollowing out' of Japanese industry as Japanese-based transnationals move production overseas, raises issues similar to those concerning deindustrialisation and transnationals in Britain in the 1980s (see Nagata (1995) and Takenaka (1991) reported in Ramstetter (1997), MITI (1997), Bailey (1999b) and Tomlinson and Cowling (1999)).

In the following section we consider the most recent attempt to 'deregulate' industrial development, in the form of the MAI and subsequent discussions. Although our overall concerns are with the impact on democracy and development, and in particular the balance of power between communities and transnationals, we will be concentrating here on the implications of such an agreement for corporate accountability. In doing so we will be emphasising the importance of accounting to accountability, not simply in terms of providing information but also in its facilitating action (Stewart, 1984). In particular, we question the appropriateness of voluntary developments in reporting. 


\section{TOWARDS A MULTILATERAL FRAMEWORK ON INVESTMENT}

The Multilateral Agreement on Investment (MAI) was recently proposed by the members of the Organisation for Economic Co-operation and Development (OECD). Originally due to be signed in 1997, and then more recently in April 1998, it now appears that commentators are unwilling to predict when any form of framework agreement will be reached (Financial Times, 21 October 1998). The proposed MAI and subsequent discussions over a multilateral framework on investment are the latest in a series of policy developments intended to liberalise international trade, following, most notably the General Agreement on Tariffs and Trades (GATT) and the North American Free Trade Agreement (NAFTA).

The draft MAI proposed to remove all national controls on foreign investors, and was seen by advocates as an important step in the development of the global economy, 'We are writing the constitution of a single global economy' claimed Renato Ruggerio, director-general of the World Trade Organisation, as reported in Rowan (1998).

The primary aim appears to have been the protection of international investment, with all foreign investors in member countries to be treated in the same way as domestic firms. As a consequence transnationals, which are increasingly dominating world trade and investment (United Nations, 1993 and 1997), would face fewer restrictions on their movement of funds. There would be no restrictions on the repatriation of profits, which advocates argued would increase capital flows around the world. The MAI was also expected to attract more Foreign Direct Investment (FDI) to developing countries, reducing the need to provide competitive incentives to transnationals, although it should be borne in mind that developing countries 
were not party to the development of the draft agreement. It was also proposed that where restrictions were imposed which harmed the rights of investors (except most probably in sectors such as defence, though not in other potentially significant sectors such as land, minerals and forests (Das, 1997)), transnationals were to be able to sue national and local governments at an international tribunal. Governments were not to have a right of appeal.

The agreement was drafted with the intention of applying to OECD countries only in the first instance, although the remaining nations of the world were to be invited to sign, and be bound by the agreement. It was proposed that signing-up involved an initial commitment of 15 years and a notice period of 5 years on withdrawal (Rowan, 1998).

In some respects the MAI and ongoing discussions can be seen as a logical development from the enormous growth in FDI in recent years. It was essentially concerned with the protection of investment, investment liberalisation and dispute settlement' (Shelton, 1997), based on three basic principles; non-discrimination, no entry restrictions and an absence of special conditions. It sought to ensure a 'uniform, stable and predictable environment in which (transnational) enterprises can conduct their activities' (Kang, 1997).

However, following our earlier discussion, and drawing on the transnational monopoly capitalism perspective we have adopted (Cowling and Sugden, 1987), we would suggest that such deregulation and increase in the freedom of transnationals and capital would likely result in costs for workers and communities. Nations and communities would lose democratic control over their economy, no longer being able to set specific conditions (performance 
requirements) on inward investment (e.g. in relation to ceilings on equity, restrictions on ownership, employment, the environment, local supplies and technology transfer). They would, however, have been free to continue to 'subsidise' transnationals and so it was likely that competition between nation states would have continued. In addition governments would have been unable to restrict investment within its borders from firms located in any particular country even where the firm had a poor record on environmental and social performance (e.g. human rights violations) (Chalmers, 1997).

The proposed MAI involved subordinating 'the rights of elected governments to set national economic policy to the right of transnational corporations and investors to conduct business' (Bleifuss, 1998). As a consequence countries may have been forced to bid down in order to attract investment, yet would not have been able to impose sanctions on firms who behave in an economically, socially, politically or environmentally undesirable manner. Countries would have been unable to guide foreign investment to particular sectors and away from others, and would not have been able to provide incentives solely to domestic corporations (for example it was expected that preferential treatment for small businesses would have been challenged, and it may not have been possible to subsidise local cultural industries, such as French literary and artistic work (Bleifuss, 1998)). As a consequence governments would have been less able to protect their economies, local businesses, workers and the environment. In addition the MAI's focus on investment ignored the importance of exporting labour services for some developing countries (Mukherjee, 1996). Since developing countries were not party to the negotiations, their interests were not represented directly in 
any negotiations (for example, see Ramaiah (1997) on concern in India over the possible effects of the proposed MAI).

As we have indicated, the proposed MAI and current framework discussions followed previous liberalisation of trade, including the GATT (which sought to remove all non-tariff trade barriers in order to maximise world trade and create a global economy (Goldsmith, 1997), thus threatening enlightened social and environmental legislation in the name of protectionism), and the NAFTA (which has seen the Canadian and Mexican governments being sued by transnationals as a consequence of their national environmental protection measures (Rowan, 1998)). Together such agreements are developing new rights for transnationals without specifying any additional responsibilities. Yet responsibilities could be incorporated, particularly in regard to improving the accountability of transnationals. Hirst and Thompson (1996) have suggested that a multilateral agreement could draw on previous efforts by the UN to draw up a Code of Conduct for transnationals, and so cover matters such as the rights of labour and conditions of work, the rights of governments to determine certain economic policies, develop a proper disputes mechanism open to governments, and incorporate protocols on environmental protection. In contrast the proposed MAI was more of an incomplete contract between transnationals and communities, where the former have negotiated greater freedom/power without additional responsibilities. At no stage was there any indication of attempts to democratise transnationals, or to improve their accountability.

Of particular importance to us here was the absence of any specific provisions in the MAI regarding corporate accountability and disclosure. Clearly such would be inconsistent with the deregulating ideology, yet we would argue that 'deregulation' necessitates an improvement 
in corporate accountability, and reporting in particular. The over-riding desire to promote the negative freedom (i.e. freedom from control or intervention) of transnationals, preserving their choice and reducing the scope for democratically elected government to regulate their affairs, undermines the positive freedom (i.e. freedom or right to do certain things, e.g. contributing to strategic decision making) of the majority (Bailey, 1999a), in a manner similar to attempts to promote free trade through GATT, NAFTA, etc. (Cowling and Sugden, 1998b). Such market freedoms leave communities even more vulnerable to the unelected, and so necessitates the acceptance of greater responsibility and consequent accountability by transnationals. It also requires us to consider whether further accountability, and specifically reporting, can be satisfactorily developed on a voluntary basis.

This focus on deregulation and greater freedom for transnationals, with consequent failure to address issues of sovereignty, minimum standards (concerning the environment and labour), accountability and disclosure may go some way to explaining the resistance of many countries, particularly France, as well as non-governmental organisations, to the latest draft of the MAI (Financial Times, 21 October 1998). The opposition of the French government, in particular, stalled the MAI in December 1998 (OECD, 1998). Its concerns were not isolated. The European Parliament condemned the MAI's inherent imbalance of power between firms and governments and also its lack of transparency (United Nations, 1998). Similarly, Britain's House of Commons criticised the MAI's lack of consideration of environmental and social issues, its lack of transparency, and its exclusion of developing countries (House of Commons, 1999). Yet despite such criticisms, discussions on the substance of the MAI will continue at the World Trade Organisation's Working Group on Trade and Investment. The 
European Commission, in particular, sees the shift to the WTO as a real opportunity to continue the MAI at a new forum, its 'ideal result' being almost exactly the basic provisions of the MAI (European Commission, 1998). The name and venue may have changed, but the game remains the same: the United States, the European Commission and transnational corporations continue to aim for an MAI-style multilateral framework on investment.

\section{THE NEED FOR GREATER ACCOUNTABILITY: A POLITICAL ECONOMY}

\section{$\underline{\text { APPROACH }}$}

The primary accountability of transnationals' economic activity is generally to providers of financial capital. In Britain, and most industrialised market economies, this is governed largely by one or more of the law, the accounting profession and the Stock Exchange. For example the lodging of information with the Registrar of Companies, and for public companies the wide dissemination of annual reports, affords a degree of public accountability in Britain.

In general very little has changed this century regarding the nature of such financial accountability. The volume of information reported has grown, yet the basic system remains largely the same historic cost model of the last century ${ }^{10}$. The traditional view is that external financial accounting statements should capture only those costs and revenues that are internal to an organisation (Solomons, 1991) in order to measure and communicate economic information which will be relevant to decision makers (primarily providers of financial capital and their advisers). As a consequence current accounting practice deals only with a 
subset of all economic exchange transactions (Tinker, 1985), relying on market exchanges, and in particular the concepts of money measurement and entity. Although there are serious doubts as to the consistency between accounting practice and the demands of the market system, the entity and money measurement concepts can be seen as justification of the need to focus on only those transactions entered into by the firm (rather than its impact), accounted for in financial terms (Tinker, 1985).

This traditional view of accounting can be criticised as partial and one sided (Morgan, 1988). In some respects one could argue that accounting and accountants are aware of the deficiencies and are attempting to develop accountings which broaden the focus. We have seen criticisms of traditional accounting for failing to reflect new managerial concerns with quality, etc. (e.g. Kaplan, 1984), developments in public sector accounting such as value for money, and concern for the environmental impact of business (Gray, 1990; Gray, Bebbington and Walters, 1993). Yet the emphasis in accounting practice as illustrated by the annual report and accounts remains largely the same. In many respects the direction of change in external reporting practice appears to be more concerned with refining a picture of so called economic reality (e.g. ICAS, 1988; Accounting Standards Board, 1993), and continues to be explored very much within the neo-classical/marginalist paradigm.

Of particular interest to us here is that little attention is paid to market imperfections or aberrations in the analysis of multinational and monopoly business (Tinker, 1980). Multinational and international accounting are suggested to offer opportunities for radical and dramatic changes in accounting (Tinker, Merino and Neimark, 1982), yet there are few signs 
that scholars or practitioners have taken this opportunity. Most accounting research appears to ignore the fact that the economy is dominated by such large transnational corporations, often operating in oligopolistic or monopolistic markets (Cooper and Sherer, 1984), and consequently fails to reflect general social and human consequences as well as the wider strategic impact of such organisations (Morgan, 1988). Following our earlier discussion of transnationals, which followed a transnationals monopoly capitalism perspective (Cowling and Sugden, 1987), our critique of transnationals' corporate reporting practices follows a political economy approach, which recognises the underlying and irresolvable conflict of interest between labour and capital (Cooper \& Sherer, 1984; Ogden \& Bougen, 1985). In doing so we offer an analysis which is explicitly normative, descriptive and critical (Cooper and Sherer, 1984). Specifically in regard to accounting, a political economy of accounting (PEA) approach considers the functions of accounting within the economic, social and political context in which it operates (Cooper and Sherer, 1984), where an accounting system can only be understood in the context of the wider social system in which it is to be found (Puxty, 1986). In a society characterised by class conflict, communication will systematically distorted. Following political economy theory, accounting reports are seen as a tool for "constructing, sustaining and legitimising political and economic arrangements, institutions and ideological themes which contribute to corporations' private interests" (Guthrie \& Parker, 1990).

Annual reports and accounts can therefore be seen as a partisan writing of history, through which individuals and institutions define themselves and are defined by others (Tinker and Neimark, 1988). Corporate reports may therefore reduce the emphasis on any particular 
matter, must interpret events and construct a history of social and economic events (Tinker and Neimark, 1988). In doing so traditional accounting reports tell one less about the impact of a transnational corporation than about its financial performance. In respect of the previously identified issues of concern to Western governments in recent years, it is unlikely that one would find many details, for example, of pricing and marketing policies and practices, training, productivity, transfer pricing, job quality, 'rate of exploitation', imports and exports, spending in local economies, consumption of resources, political involvement and environmental impact ${ }^{11}$.

While it may be argued that recent developments such as the MAI, GATT and NAFTA emphasise the ideas of marginalism and can be seen as another brick in the house of monopoly capitalism, this emphasis on the market ironically requires us to consider the role of accounting information and the possibility that regulation is needed. The limiting of regulation and specific requirements for FDI can be argued to require a more complete picture of corporate activity. Since the MAI and similar agreements rely on an assumption that additional conditions should not be imposed on transnationals it implies that the wider social and environmental impact of transnationals can be ignored, yet without information on individual corporate performance and impact how can we be sure that this is acceptable to the community? How can the community decide whether to support elected representatives and their policies towards transnationals? How can communities continue to support the independence and rights attributable to capital (e.g. legal persona and limited liability)? Accepting that the MAI and similar agreements seek to ensure governments do not impose political conditions on transnationals, the absence of reporting on the wider economic, social 
and environmental consequences of transnationals will also limit the freedom of the community (e.g. in its purchasing or employment decisions). If governments cannot act to implement the will of society then surely communities must be informed of corporate impact so that individuals or groups can decide how to invest their labour or consume, and whether to allow agreements such as the MAI to exist. Without this information liberalisation cannot be seen as a rational economic strategy but rather an ideology. The absence of wider accountability and reporting means that the opportunities to challenge the ideas of the economic system will be limited.

Our position, therefore, recognises that accounting reports play an important part in forming world views or social ideology (Tinker \& Neimark, 1987), in this case giving management an opportunity to present its view of the world, particularly in regard to the performance and impact of transnationals, and, where appropriate, choosing what to comment on and what to ignore. Non-disclosure of economic, social or environmental information may be seen as a means of protecting business self-interest and as an effective means of intervention (preventing participation of other interests) and confusion in itself. Management, as we have stressed, may seek to 'confuse, mystify or convince' in its accounting (Cooper, 1984, p 128), and, we would argue, may have more incentive to do so where there are few regulations governing industrial development.

Following a PEA approach encourages us to focus on accounting's contribution to the distribution of wealth and power in society (accounting techniques enable elite groups and their agents to concentrate on private wealth (Tinker, 1985), yet tell us very little about the 
impact of corporations); recognising the historical and institutional environment in which it operates (in this case we argue for a development in reporting practice because of the increased liberalisation of industrial development and the growing power of transnationals); and recognising the role of interests and the potential for change in accounting (e.g. we are particularly concerned with the consequences of accounting which fails to address the wider economic, social and environmental impact of transnationals, particularly in light of the well articulated concerns of western governments in recent years, not to mention our own more radical agenda) (Cooper and Sherer, 1984).

\section{LESSONS FROM USING PUBLICLY AVAILABLE INFORMATION TO MONITOR}

\section{TRANSNATIONALS}

Our earlier consideration of proposals for monitoring transnationals revealed a consistent concern with both the quality and quantity of disclosure. Information (accounting) was seen to be an essential element of accountability, so as to allow the community and its representatives to see whether they are satisfied with their relationship with transnationals and its consequences. The central importance of information is illustrated in Barrat Brown's (1986) suggestion that the first point of action by trade unions and local authorities, in a strategy to combat the power of transnationals, would need to be the establishment of a continuous flow of information. This would seem most important if, as Cowling suggests, there is at the moment "no accurate record of their (transnationals') global activities" (Cowling, 1990). Certainly our earlier critique suggests that traditional corporate annual reports are incomplete. This view is supported by the transnationals debate in the USA, 
where it was recognised that policy was being hampered by the absence of information (Bailey, Harte and Sugden, 1992b).

An important aspect of any regulation involves taking a systematic approach which involves monitoring, checking or controlling activities. A critical commodity used by any regulator is information and a central feature would be a continuous or regular record of events (Bullock et al, 1988). Such monitoring activity is widely practised in our economy and society, for example: government departments monitor business ${ }^{12}$, parent companies monitor subsidiaries, companies monitor rivals, companies monitor their markets/customers, and investors monitor investment opportunities. In each case information is collected in order to inform and/or allow regular control or action in some form. In some respects this focus on the availability of information for regulation is similar to the traditional emphasis on information for investment purposes. In that case information is seen as a commodity, needed to expand the number of trading opportunities, to improve real production decisions, and to eliminate or reduce social costs associated with asymmetric information (Walker, 1988). The objectives of a monitoring unit would seem to be not too dissimilar, in that it would be seeking to consider the consequences of transnational's activities (returns to the community) in order to inform economic policy.

However accounting for the wider economic and social consequences of corporate performance is at best a marginal activity (Gray et al, 1995). Despite extensive publicity and advocacy, most recently particularly in regard to the environment, there is little evidence of widespread, comprehensive and reliable reporting. What reporting does occur is substantially 
voluntary, and so depends for its existence, never mind its nature and form, on managerial discretion. Of course such discretion is subject to influences, such as the market for finance, the market for managerial services and audit (Benston, 1982), but in the main these are narrow financial incentives to report. Yet voluntary disclosure in a society characterised by unequal distributions of power and influence and conflicts of interest, is likely to reflect the values of dominant groups, and so be used as a means to inform in a way which seeks to 'mislead, mystify and legitimate' certain interests and action (Cooper, 1984).

In addition, previous voluntary reporting on the wider social and environmental consequences of corporate performance has differed substantially from actual performance (see Ingram and Frazier, 1980; Wiseman, 1982; Rockness, 1985). More recently studies have shown that voluntary corporate reporting has excluded information on the negative aspects of environmental performance (Deegan and Rankin, 1996; Deegan and Gordon, 1996) and equal opportunities impact (Adams and Harte, 1998).

We might expect something similar in the case of an MAI-type agreement. The MAI was premised on the need to limit restrictions on transnationals and their investment. The preference for market based solutions assumes that sufficient information will be made available to allow participants to make informed decisions. This too will be left to the market. Yet our characterisation of transnationals as powerful agents (becoming even more so) suggests that the community and its representatives would be in a weaker position should an MAI-type agreement be introduced, made worse by the absence of adequate disclosure. The indications from previous attempts to monitor a transnational, using a framework of 
potential relevance to governments, suggested that a reliance on what firms are willing to reveal would severely curtail the potential of a monitoring unit. Drawing largely on the corporate annual report, the more detailed 20F filing with the SEC in the USA, press reports and stockbrokers' and analysts' reports the performance and impact of Glaxo plc was examined $^{13}$.

Although certain aspects of performance and impact were reported, the attempt to monitor Glaxo revealed that very little information is provided regarding the overall structure of the group and in particular the flow of goods and services within the group. While a list of major subsidiaries and associate companies is provided, with limited segmentation of the results, there was little reported which might assist one in assessing local purchasing, employee involvement in management or the degree of centralisation of decision making. Similarly little is reported on marketing, patents (e.g. expiry), pricing, product quality (pharmaceutical firms are subject to strict regulation, yet there is no mention of government inspections) and distribution, and virtually no forecast data. Interestingly brokers' reports did reveal further details of patent expiries etc., quoting the firm as the appropriate source of such data, and there did appear to be more reported on research and development in this source (again as a result of company information) than in the annual report or similar corporate sources. There was also little reported on the group's relationship with government, a matter of some concern given the size of the firm, it impact on the exchequer and balance of payments, and that the state is a significant customer. 
While these findings might not be a great surprise they do alert us to the risks of relying on corporate voluntary disclosure as a means of satisfying demands for corporate accountability. A transnationals monitoring unit would barely function without the ability to regulate corporate disclosure.

\section{$\underline{\text { CONCLUSION }}$}

Optimistically we could conclude that 'every social order carries the seeds of its own destruction' (Ascherson, 1998). If, as Ascherson suggests, the global free market is the 'most powerful and arrogant world order in human history', then attempts to develop an MAI-style multilateral framework on investment may see transnationals overplay their hand, and force communities to respond to the further loss of sovereignty. This may go some way to explaining the rejection of the latest draft of the MAI agreement.

We have argued that giving even freer reign to transnationals will have adverse consequences for the community. Leaving industrial development to the market means that as a social structure it will support the interests of the most powerful participants. Markets need to be controlled, preferably by democratically elected and accountable organisations, rather than undemocratic transnationals pursuing private interests. Such control is proposed here in the form of a transnationals monitoring unit, with the power to regulate disclosure.

While a number of important issues appear to remain unresolved regarding the development of a multilateral framework on investment (e.g. cultural factors, subnational government action, and labour and environmental standards) (Ley, 1997; Atkinson, 1998), the creation of greater freedom for transnationals through the institution of the market, forces us to address 
the question of control and in particular the role and responsibilities of the state. '(B)ringing global economic institutions under the authority of political institutions is essential to protect the environment, human rights and job possibilities around the world. Making both accountable to the people is essential if the new world economic order is to be democratic, and if it is not democratic it will enjoy neither legitimacy nor stability.' (Barnet and Cavanagh, 1994). Perhaps Ascherson's optimism is well placed after all.

\section{$\underline{\text { REFERENCES }}$}

Accounting Standards Board (1995), Statement of Principles for Financial Reporting, Exposure Draft, Accounting Standards Board, London.

Adams, C. and Harte, G. (1998), Towards Corporate Accountability for Equal Opportunities Performance, mimeo.

Amnesty International (1998), Human Rights Principles for Companies, Amnesty International, London.

Ascherson, N. (1998), We live under the most arrogant of all world orders, but it will not last, The Independent on Sunday, 25 January.

Atkinson, M. (1998), Rich Nations Retreat, The Guardian, 24 April.

Bailey, D. (1999a), Freedom, Markets and Industrial Policy, Industrial Development Policy Discussion Paper, No. 4, Universities of Birmingham and Ferrara: Institute for Industrial Development Policy.

Bailey, D. (1999b), The End of the "Miracle"? Deregulation, Free Markets and Strategic Failure in the Japanese Economy, Occasional Papers in Industrial Strategy, No. 47, University of Birmingham, Research Centre for Industrial Strategy.

Bailey, D., Harte, G. and Sugden, R. (1992), US Policy Debate Towards Inward Investment, Journal of World Trade,_Vol. 26, No. 4, pp. 66-93.

Bailey, D., Harte, G. and Sugden, R. (1994a), Making Transnationals Accountable, Routledge, London. 
Bailey, D., Harte, G. and Sugden, R. (1994b), Transnationals and Governments, Routledge, London.

Baran, P.A. and Sweezy, P.M. (1966), Monopoly Capital, Penguin, Harmondsworth.

Barrat Brown, M. (1986), 'Can European Workers Cope with Transnational Capital? in K. Coates (ed.), Joint Action for Jobs, Spokesman, Nottingham.

Barnet, R. J. and Cavanagh, J. (1994), Global Dreams: Imperial Corporations and the New World Order, Simon and Schuster, New York.

Benston, G. J. (1982), Accounting and Corporate Accountability, Accounting, Organizations and Society, Vol. 7, No. 2, pp 87-105.

Bleifuss, J. (1998), Building the Global Economy, In These Times, 11 January, pp 13-15.

Briston, R. (1984), Accounting Standards and Host Country Control of Multinationals, British Accounting Review, Vol. 16, No. 1, pp 12-26.

Buckley, P. J. and Casson, M. (1976), The Future of the Multinational Enterprise, Macmillan, London.

Bullock, A., Stallybrass, D. and Trombley, S. (1988), The Fontana Dictionary of Modern Thought,2nd edition, Fontana, London.

Cantwell, J. (1991), A Survey of Theories of International Production, in C. Pitelis and R. Sugden (eds.), The Nature of the Transnational Firm, Routledge, London.

Chalmers, D. (1997), The MAI: a Wrong Type of Globalisation, Scottish Trade Union Review, No. 84, September - October, pp 24-25.

Coase, R. H. (1937), The Nature of the Firm, Economica, Vol. 4.

Cooper, D. (1984), 'Information for Labour' in Carsberg, B. V. and Hope, T., 1984, Current Issues in Accounting (2nd edition, Philip Allan), Deddington.

Cooper, D. J. and Sherer, M. (1984), The Value of Corporate Accounting Reports: Arguments for a Political Economy of Accounting, Accounting, Organizations and Society, Vol. 9, No. 3/4, pp. 207-32.

Council on Economic Priorities Accreditation Agency (1997), Social Accountability 8000, CEPAA, London.

Cowling, K (1982), Monopoly Capitalism, Macmillan, London. 
Cowling, K (1990), A Strategic Approach to Economic and Industrial Policy, in K. Cowling and R. Sugden (eds.), A New Economic Policy for Britain - Essays on the Development of Industry, Manchester University Press, Manchester.

Cowling, K. and Sugden, R. (1987), Transnational Monopoly Capitalism, Wheatsheaf, Brighton.

Cowling, K. and Sugden, R. (1993), A Strategy for Industrial Development as a Basis for Regulation, in R. Sugden (ed.), Industrial Economic Regulation - A Framework and Exploration, Routledge, London.

Cowling, K. and Sugden, R. (1994), Beyond Capitalism, Towards a New World Economic Order, Pinter, London.

Cowling, K. and Sugden, R. (1998a) The Essence of the Modern Corporation: Markets, Strategic Decision-Making and the Theory of the Firm, The Manchester School, Vol. 66, No. 1, pp 59-86.

Cowling, K. and Sugden, R. (1998b) Strategic Trade Policy Reconsidered: National Rivalry Vs Free Trade Vs International Co-operation, Kyklos, Vol. 51, pp 339-335.

Das, B. L. (1997), A Critical Analysis of the Proposed Investment Treaty in WTO, @http://www.panasia.org.sg/souths/twn/title/ana-ch.htm

Deegan, C. and Gordon, B. (1996), A study of the Environmental Disclosure Practices of Australian Corporations, Accounting and Business Research, Vol. 26, No. 3, pp 187-99.

Deegan, C. and Rankin, M. (1996), Do Australian Companies Report Environmental News Objectively?, Accounting, Auditing and Accountability Journal, Vol. 9, No. 2, pp 50-67.

Dicken, P. (1998), Global Shift. Transforming the World Economy, Paul Chapman, London.

Dunning, J. H. (1977), Trade Location of Economic Activity and the Multinational Enterprise: A Search for an Eclectic Approach, in B. Ohlin, P. Hesselborn and P.M. Wijkman (eds.), The International Allocation of Economic Activity, Macmillan, London.

Dunning, J. H. (1979), Explaining Changing Patterns of International Production: in Defence of the Eclectic Theory, Oxford Bulletin of Economics and Statistics_Vol. 41.

Dunning, J. H. (1980), Towards an Eclectic Theory of International Production: Some Empirical Tests, Journal of International Business Studies, Vol. 11.

Dunning, J. H. (1981), Explaining the International Direct Investment Position of Countries: Towards a Dynamic or Developmental Approach, Weltwirtzchaftliches Archiv, Vol. 117.

Dunning, J. H. (1993), Multinational Enterprises and the Global Economy, Addison-Wesley, Wokingham. 
European Commission (1998), DG1A Note to art. 113 Committee Discussion Paper: Trade and Investment. M. D. 642/98, 15 December 1998, European Commission, Brussels.

Goldsmith, E. (1997), Can the Environment Survive the Global Economy?, The Ecologist, Vol. 27, No. 6, November/December.

Gray, R. H. (1990), The Greening of Accountancy: The Profession after Pearce, Chartered Association of Certified Accountants, London.

Gray, R. H., Bebbington, J. and Walters, D. (1993), Accounting for the Environment, Paul Chapman Publishing, London.

Gray, R. H., Kuohy, R. and Lavers, S. (1995), Corporate Social and Environmental Reporting: A Review of the Literature and a Longitudinal Study of UK Disclosure, Accounting, Auditing and Accountability Journal, Vol. 8, No. 2, pp 47-77.

Gray, S. J., Shaw, J. C. and McSweeney, L. B. (1981), Accounting Standards and Multinational Corporations, Journal of International Business Studies, Spring/summer, pp 121-135.

Guthrie, J. and Parker, L (1990) Corporate Social Disclosure Practice: a Comparative International Analysis, Advances in Public Interest Accounting, Vol. 3, pp 159-175.

Hamilton, G. (1984), The Control of Multinationals: What Future for International Codes of Conduct in the 1980s, IRM Multinational Reports, Geneva.

Harte, G. and Sugden, R. (1990), A Proposal for Monitoring Transnational Corporations, in K. Cowling and R. Sugden (eds.), A New Economic Policy for Britain - Essays on the Development of Industry, Manchester University Press, Manchester.

Harte, G. and Sugden, R. (1992), Co-operation in the European Community to Regulate Transnational Corporations, in Koubek, N., Gester, H. and Wiedemeyer, G. R., Richtlinien fur das Personal - Management in Internationalen Unternehmungen, Nomos verlagsgesellschaft, Baden-Baden.

Held, D. (1988), Farewell Nation State, Marxism Today, December, pp. 12, 13, 15-17.

Hennart, S. F. (1991), The Transaction Cost Theory of the Multinational Enterprise, in C. Pitelis and R. Sugden (eds.), The Nature of the Transnational Firm, Routledge, London.

Hines, R. D. (1989), The Socio-political Paradigm in Financial Accounting Research, Accounting, Auditing and Accountability Journal, Vol. 2, No. 1, pp. 52-76.

Hines, R. D. (1991a), The FASB's Conceptual Framework, Financial Accounting and the Maintenance of the Social World, Accounting, Organizations and Society, Vol. 16 No. 4, pp. 313-331. 
Hines, R. D. (1991b), On Valuing Nature, Accounting, Auditing and Accountability Journal, Vol. 4 No. 3, pp. 27-29.

Hirst, P. and Thompson, G. (1996), Globalization in Question: The International Economy and the Possibilities of Governance, Polity Press, Cambridge.

Hood, N. and Young, S. (1979), The Economics of Multinational Enterprise, Longman, London.

House of Commons (1999), Environmental Audit Committee First Report on the MAI, 8/2/99. House of Commons Paper No. HC58-1 (1998-99), HMSO, London.

Hughes, J. (1986), Industrial Democracy and Socialist Priorities, in K. Coates (ed.), Freedom and Fairness, Spokesman, Nottingham.

Hymer, S. H. (1960), The International Operations of National Firms, published in 1976, MIT Press, Cambridge, Mass.

Ingram, R. and Frazier, K. (1980), 'Environmental Performance and Corporate Disclosure', Journal of Accounting Research, Vol. 18, No. 2, pp. 614-22.

Institute of Chartered Accountants of Scotland (1988), Making Corporate Reports Valuable, Kogan Page, London.

Kang, K-S. (1997), Opening Address, in OECD, Multilateral Agreement on Investment; State of Play April, 1997, OECD, Paris.

Kaplan, R. (1984), Yesterday's Accounting Undermines Production, Harvard Business Review, July/August, pp. 95-101.

Kindleberger, C. P. (1969), American Business Abroad, Yale University Press, New Haven.

Labour Party (1977), International Big Business: Labour's Policy on the Multinationals, Labour Party, London.

Labour Party (1987), New Industrial Strength for Britain, Labour Party, London.

Lehman, C. and Tinker, T. (1987), The Real Cultural Significance of Accounts, Accounting, Organizations and Society, Vol. 12, No. 5, pp. 503-22.

Ley, R. (1997), The Scope of the MAI, in OECD, Multilateral Agreement on Investment State of Play in April, 1997, OECD, Paris.

MITI (Ministry of International Trade and Industry) (1997), Structural Reform of the Japanese Economy, http://www.jef.or.jp/news/97.nov.html 
Marglin, S. A. (1974), What do Bosses do? Part 1, Review of Radical Political Economics, reprinted in Andre Gorz (ed.), 1976, The Division of Labour, Harvester, Brighton.

Morgan, G. (1988), Accounting as Reality Construction: Towards a New Epistemology for Accounting Practice, Accounting, Organizations and Society,_Vol. 13, No. 5, pp. 477-85.

Mukherjee, N. (1996), Multilateral Investment Agreement and Poor Countries, Economic and Political Weekly, 23 November, pp 3045-6

Murray, R. (1981), Multinationals Beyond the Market - Intra Firm Trade and the Control of Transfer Pricing, Harvester, Brighton.

Nagata, M. (1995), The Asia-Pacific Region in the 21st Century: Future relations among the United States, Japan and Asia, in F. G. Adams, T. Katsuhara, and K. Nogami (eds), Interdependence and New Directions for Development Policy in East and Southeast Asia, International Centre for the Study of East Asian Development, Kitakyushu.

Ogden, S. and Bougen, P. (1985) A Radical Perspective on the Disclosure of Information to Trade Unions, Accounting, Organizations and Society, Vol. 10, No. 2, pp 211-224.

OECD (1998), Informal Consultations on International Investment, (OECD Press Release 3/12/98), http://www.oecd.org/daf/cmis/mai/mainindex.htm

People, J. and Sugden, R. (1999), Divide and Rule by Transnational Corporations, in C. Pitelis and R. Sugden (eds.), The Nature of the Transnational Firm, second edition, forthcoming, Routledge, London.

Puxty, A. G. (1986), Social Accounting as Imminent Legitimation: A Critique of Technist Ideology, Advances in Public Interest Accounting, Vol. 1, pp. 95-112.

Ramaiah, B. B. (1997), Towards a Multilateral Framework on Investment, Transnational Corporations, Vol. 6, No. 1, pp. 117-121.

Ramstetter, E. D. (1997) Export Performance and Foreign Affiliate Activity in Japan's Large Machinery Firms, Transnational Corporations, Vol. 6, No. 3, December, pp 113-133.

Rockness, J. W. (1985), 'An Assessment of the Relationship between US Corporate Environmental Performance and Disclosure', Journal of Business Finance and Accounting, Vol. 12, No. 3, pp. 339-54.

Roddick, A. (1999), Transnationals must face responsibilities, Financial Times, 16/1/99, 8.

Rowan, D. (1998), Meet the New world Government, The Guardian, 13 February, p 15.

Shelton, J. R. (1997), Opening Address, in OECD, The Multilateral Agreement on Investment: State of Play as of February, OECD, Paris. 
Sklair, L. (1991), Sociology of the Global System, Wheatsheaf, Hemel Hempstead.

Solomons, D. (1991), Accounting and Social Change: A Neutralist View, Accounting, Organizations and Society, Vol. 16, No. 3, pp. 287-95.

Standing Commission on the Scottish Economy (1990), Final Report, Standing Commission on the Scottish Economy, Glasgow.

Steward, F. (1989), New Times, Green Times, Marxism Today,_March, pp. 14, 15, 17.

Stewart, J. D. (1984), The Role of Information in Public Accountability, in A. Hopwood and C. Tompkins (eds.), Issues in Public Sector Accounting, Philip Allen, Oxford.

Sugden, R. (1990), A Warm Welcome for Foreign-Owned Transnationals from Recent British Governments, in M. Chick (ed.), Governments, Industries and Markets- - Aspects of Government-industry Relations in the UK, Japan, West Germany and the USA since $1945_{2}$ Edward Elgar, Aldershot.

Sugden, R. (1992), Why Transnationals? The Significance of Divide and Rule, in G. R. Krishnamarthy (ed.), Personnel Practices in Multinational Corporations in Different Cultures.

Sugden, R. (1997), Economias Multinacionales y la Ley del Desarrolle sin Equidad, (Multinational Economies and the Law of Uneven Development), FACES, Vol. 3, No. 4, pp $87-116$

Takenaka, H. (1991), Contemporary Japanese Economy and Economic Policy, University of Michigan Press, Ann Arbor.

Tinker, A. M. (1980), Towards a Political Economy of Accounting: An Empirical Illustration of the Cambridge Controversies, Accounting, Organizations and Society, Vol. 5, pp 147-60.

Tinker, T. (1985), Paper Prophets: A Social Critique of Accounting, Holt, Rinehart and Winston, Eastbourne.

Tinker, A. W Merino, B. D. and Neimark, M. D. (1982), The Normative Origins of Positive Theories: Ideology and Accounting Thought, Accounting, Organizations and Society, Vol. 7 , No. 2, pp. 167-200.

Tinker, T and Neimark, M. (1988), The Struggle Over Meaning in Accounting and Corporate Research: A Comparative Evaluation and Critical Historiography, Accounting, Auditing and Accountability, Vol. 1, No. 1, pp. 55-74.

Tomlinson, P. and Cowling, K. (1999), The Japanese Crisis - A Case of Strategic Failure?, mimeo, Department of Economics, University of Warwick, U.K..

United Nations (1993), World Investment Report - 1993, United Nations, New York. 
United Nations (1997), World Investment Report - 1997, United Nations, New York.

United Nations (1998), World Investment Report - 1998, United Nations, New York and Geneva.

Walker, M. (1988), Information Economics and Agency Theory: Elements for a Theory of Corporate Reporting, in T. A. Lee (ed.), Making Corporate Reports Valuable - The Literature Surveys, Edinburgh, Institute of Chartered Accountants. of Scotland

Wilms Wright, C. (1977), Transnational Corporations: A Strategy for Control, Fabian Society, London.

Wiseman, J. (1982), 'An Evaluation of Environmental Disclosures Made in Corporate Annual Reports', Accounting, Organizations and Society, Vol. 7, No. 1, pp. 53-63. 


\section{$\underline{\text { ENDNOTES }}$}

1 Details of the interests shown by governments in Britain, France, Germany, Japan, and the USA over the last 30 years are outlined in Bailey, Harte and Sugden (1994b). This paper draws on their findings, and discusses the proposed development of a transnationals monitoring unit in the context of recent policies such as the Multilateral Agreement on Investment.

2 Although it can be argued that few transnationals are truly international, being nationally based and home oriented (Hirst and Thompson, 1996), we should emphasise that it is the potential to relocate which is essential here. However this national attachment does, as we will see, offer some encouragement to national governments in their dealings with transnationals.

3. Intervention is thought justified to serve the public interest (since the alternative, a radical change in the economic and social system, addressing matters of economic democracy, representation, control etc. seems less likely to succeed in the shorter term).

4. We would emphasise 'appear to' here and suggest that socially responsible behaviour is most likely to be determined by long term financial considerations, and not immediate profitability.

5 See Roddick (1999). In January 1999 the European Parliament passed a report calling for a code of conduct for European transnationals operating in the developing world, backed up by a European Monitoring Platform to ensure compliance by such transnationals.

6. Corporate accountability is largely determined by legal definitions rather than economic definitions of the firm.

7 A multinational web would be a large scale production process comprising myriads of smaller firms in a nexus of criss crossing relationships which span international borders, a multinational (rather than transnationals controlled) producion process. If an important longer-run goal of industrial policy is to foster such webs policy makers need to think beyond webs of firms, and to think of 'community webs', particular forms of network which span all interest groups affected by production activity. Yet there does appear to be some desire by European politicians to move in this direction; witness the recent report of the European Parliament calling for a code of conduct for European transnationals, backed up by a European monitoring platform (see Roddick, 1999).

8. The development of an international interest in the regulation of financial reporting, with the International Accounting Standards Committee, followed long histories of national standard setting.

9 See Bailey et al (1994b) for a review of interests over the last 30 or so years. 
10. In parallel, mainstream financial reporting research and financial accounting practice concentrates on the behaviour of shareholders and creditors, implicitly accepting the values of a market society (Hines, 1989).

11. Accounting can be seen then as a language which like any other names, bounds and separates (Hines, 1991b), and in this respect the real significance of accounting can be said to be in what it denies (Lehman and Tinker, 1987) or excludes. Social costs are seen as values (to be excluded) whereas market costs are fact (Hines, 1991a).

12. Although the Registrar of Companies simply collects annual reports some industries (e.g. banking and insurance) are more closely monitored in respect of their financial position and performance.

13. See Bailey et al (1994a) for a full analysis. 